\title{
Prevalence and Comparison of Salmonella Serotypes in Indigenous and Industrial Chicken Eggs Collected from Khorramabad Using Culture and PCR Methods
}

\section{Azar Doulat ${ }^{1}$, Mohammad Reza Mahzounieh ${ }^{1}$, Nemat Shams ${ }^{2}$, Lida Etemdfar ${ }^{2}$}

1. Department of Pathobiology, Faculty of Veterinary Medicine, Shahrekord University, Shahrekord, Iran

2. Department of Pathobiology, Faculty of Veterinary Medicine, Lorestan University, Khorramabad, Iran

\section{Article Information}

\section{Article history:}

Received: 2017/08/26

Accepted: 2018/05/16

Available online: 2018/06/30

\section{Article Subject:}

Clinical Microbiology

IJMM 2018; 12(2): 88-95

Corresponding author:

\section{Lida Etemdfar}

MSc of Bacteriology,

Department of Pathobiology,

Faculty of Veterinary

Medicine, Lorestan University,

Khorramabad, Iran

Tel: 09168424930

Email:

\section{Lida.etemadfar@yahoo.com}

Use your device to scan and read the article online

\section{Abstract}

Background and Aims: Foodborne diseases are one of the major health and economic problems in industrialized and non-industrialized countries. Salmonella serotypes have been considered as one of the most important foodborne pathogens around the world. Poultry and eggs are considered as major sources for different pathogenic Salmonella serotypes. The aim of this study was to investigate prevalence of Salmonella contamination in indigenous and industrial chicken eggs in Khorramabad during 2015-2016.

Materials and Methods: In this cross-sectional study, a total of 360 (180 indigenous and 180 industrial) eggs were collected from different part of Khorramabad area. The eggs were immediately transferred to microbiology laboratory in aseptic conditions. In order to determine Salmonella, after culture according to the reference conventional methods, the suspected colonies were confirmed using Serotyping and PCR

Results: The results showed that two samples of 180 indigenous eggs (1.1\%) were contaminated to salmonella, but there was no contamination in industrial eggs.

Conclusions: The findings of the current study indicated that although Salmonella was not found in industrial egg samples but indigenous eggs produced in small farms may be harmful to consumers and cause the spread of salmonella contaminations in the environment.

Keywords: Prevalence, Salmonella, contamination, Eggs, PCR

Copyright $\odot 2018$ Iranian Journal of Medical Microbiology. All rights reserved.

How to cite this article:

Doulat A, Mahzounieh M R, Shams N, Etemadfar L. Prevalence and Comparison of Salmonella Serotypes in Indigenous and Industrial Chicken Eggs Collected from Khorramabad Using Culture and PCR Methods. Iran J Med Microbiol. 2018; 12 (2): 88-95 


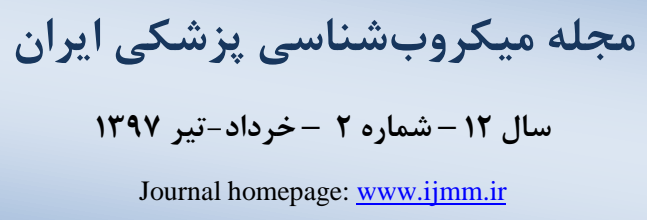

\section{بررسى شيوع و مقايسهُ سـروتيِهاى سالمونلا در نمونه تخمرغذهاى طيور بومى و صنعتى

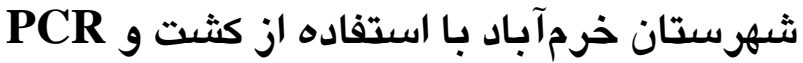

آذر دولت'، محمدرضا محزونيه'، نعمت شمس'، ليدا اعتمادفر '

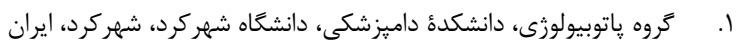

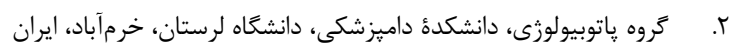

\section{جكيله}

زمينه و هدف: بيمارىهاى منتقلشونده از طريق غذا، يكى از مشكلات اصلى بهداشتى و اقتصادى بين كشورهاى صنعتى و

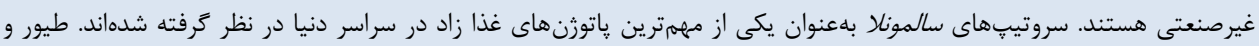

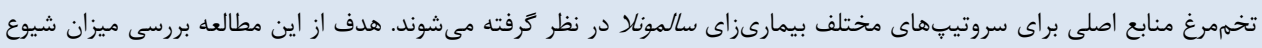

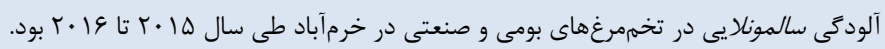

مواد و روشكار: در اين مطالعة مقطعى - توصيفى، در مجموع • وب تخممرغ (•11 بومى و •^اصنعتى) از نواحى مختلف

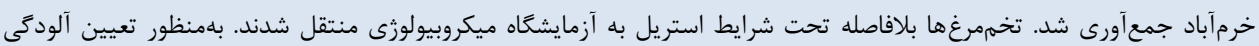

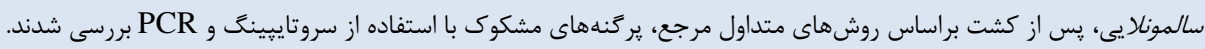

يافتهها: نتايج حاكى از آن بود كه ك نمونه از •1/ نمونه تخممرغ بومى (1/1 درصد) با استفاده از تكنيك PCR آلودكى

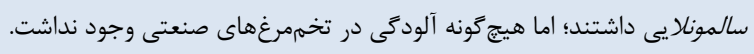

نتيجه كيرى: نتايج اين مطالعه نشان مىدهد اكرجه سالمونلا در تخممرغهاى صنعتى يافت نشد، اما تخممرغهاى بومى

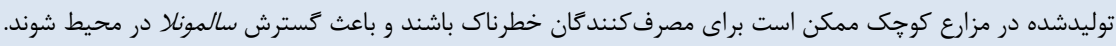

كلمات كليدى: شيوع، سالمونلا، آلودگى، تخممرغ، PCR

كبى رايت C: حق جاب، نشر و استفاده علمى از اين مقاله براى مجله ميكروبشناسى بزشكى ايران محفوظ است.

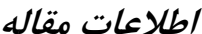

تاريخهجه مقاله

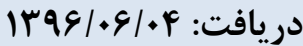

يذيرش:r

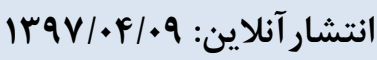

موضوع:

ميكروب شناسى بالينى

\section{IJMM1397;12(2): 88-95}

نويسنده مسئول: ليدا اعتمادفر كارشناس ارشد باكترىشناسى، گروه

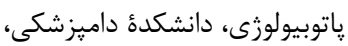
دانشخاه لرستان، خرمآباد، ايران

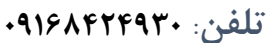
يست الكترونيك:

Lida.etemadfar@yahoo.com

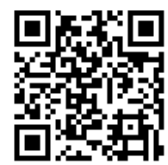

مقدمه

معمول به شكل گاستروانتريت حاد ظاهر مىشود. كودكان، افراد بالاى ه9 سال و كسانى كه دجار نقص سيستم ايمنى هستند،

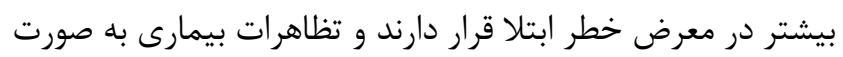
جدىتر از جمله سيتيسمى، عفونت مغز و مرگ بروز مى كند.

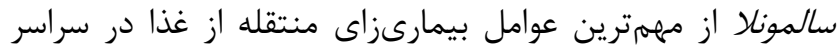
جهان در نظر گرفته شده است. سالمونلا انتريكا سرووار تيفى منى

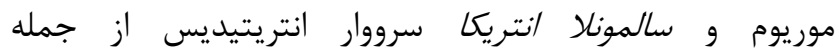

سالمونلاها باكترى متحرك، گرم منفى و بـهوازى اختيارى متعلق به خانواده انتروباكترياسه هستند. براساس جدول كافمن -

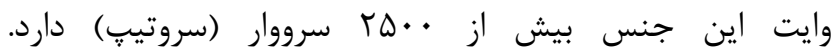
سرووارهاى مختلف اين باكترى در بسيارى از حيوانات از جمله كاو، خوك، اسب، يستانداران، خزندگًان، دوزيستان و طيور (مرغ، اردك، غاز، بوقلمون) يافت مىشوند. عفونت سالمونلا طى بـ با الى ساعت يس از قرارگيرى در معرض آلودگى باكتريايى بهطور 


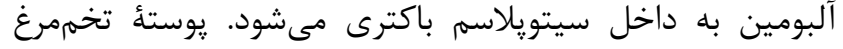

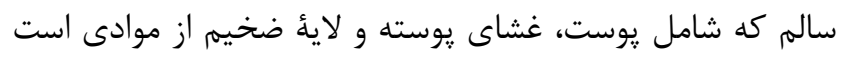

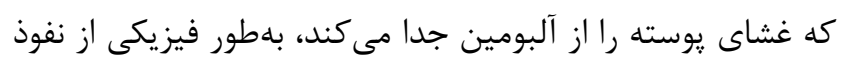

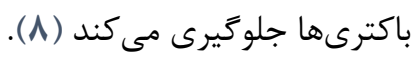

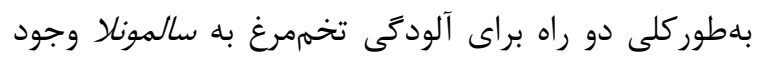

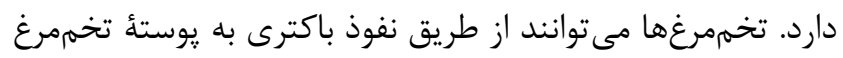

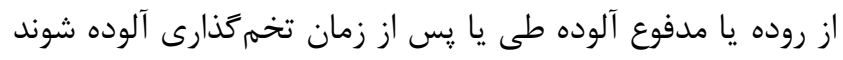

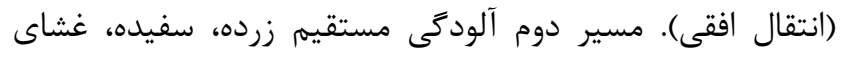

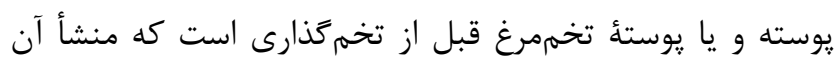

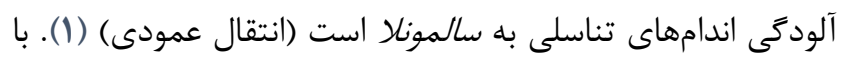

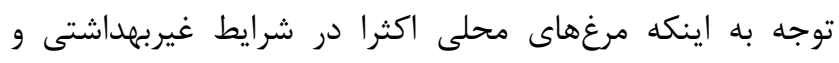

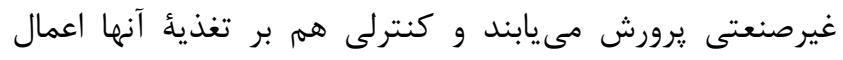

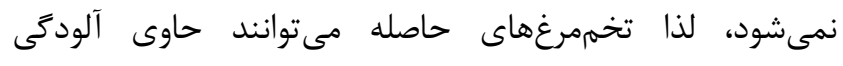

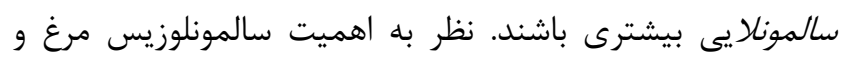
تخممرغ در ايجاد مسموميت غذايى انسان، هدف از اين مطالعه بـاني

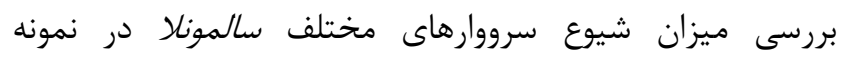
تخممرغهاى بومى و صنعتى شهرستان خرمآباد است.

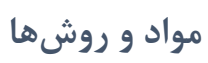

\section{جمع آورى نمونه}

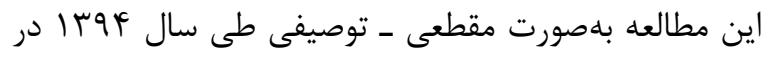

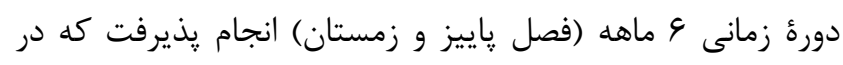

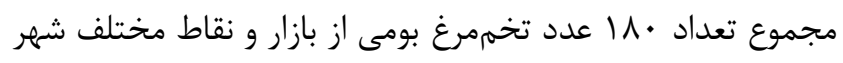

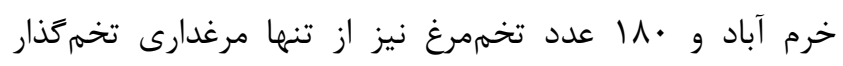

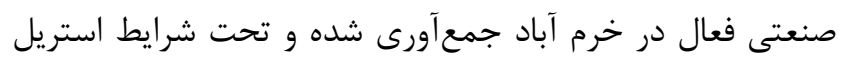
به آزمايشخاه انتقال يافتند.

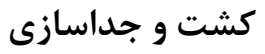

براى مرحلة بيشغنى سازى تحت شرايط استريل با كشيدن

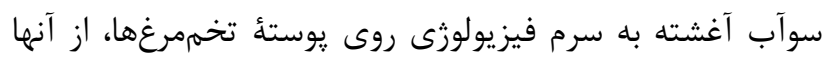

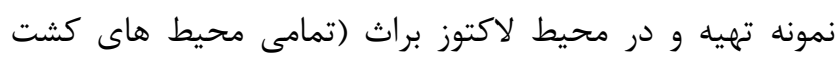

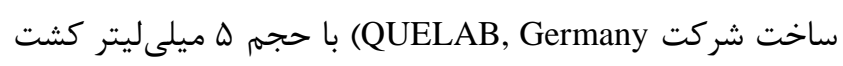

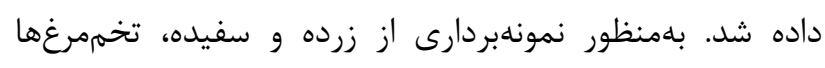

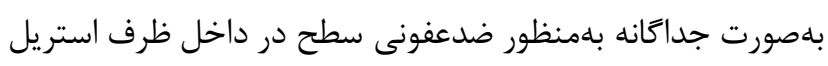

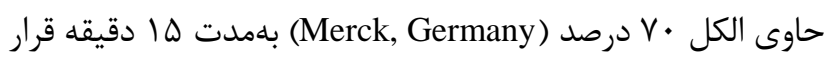

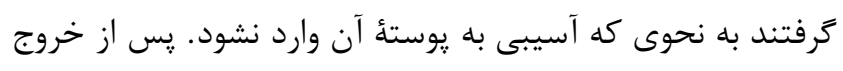

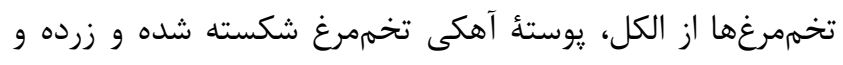

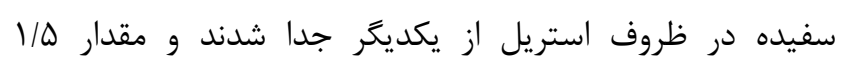

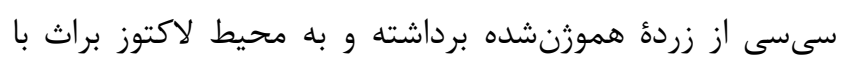

سرووارهايىاند كه اغلب از بيمارىهاى ناشى از موادغذايى جدا

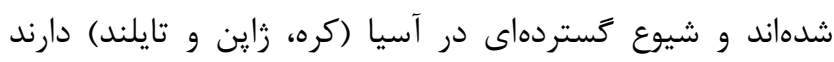

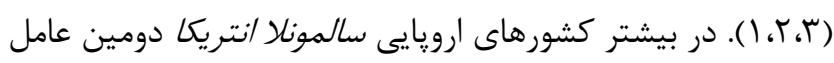

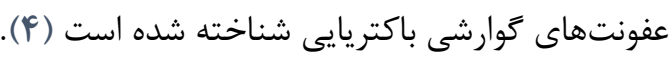

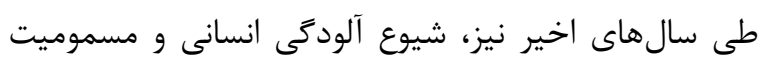
غذايى ناشى از سالمونلا بهطور خشمخيرى در ارويا، آمريكا و ديكر إنى

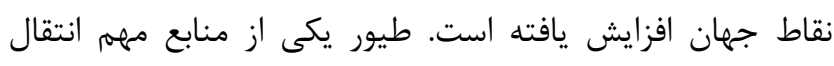

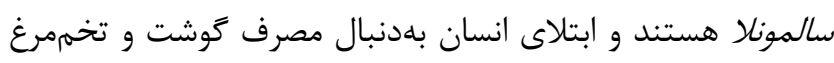

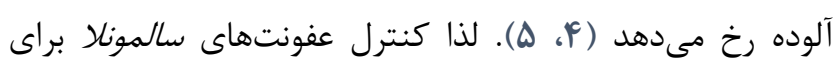

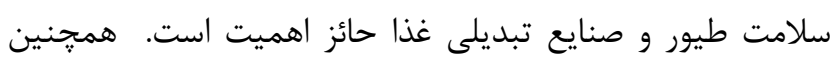

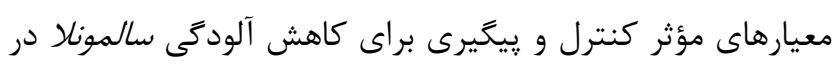

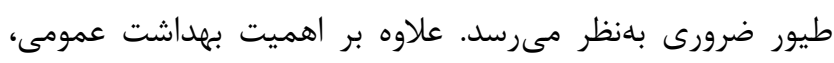

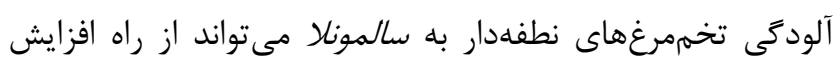

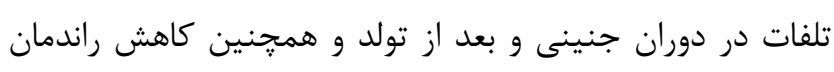

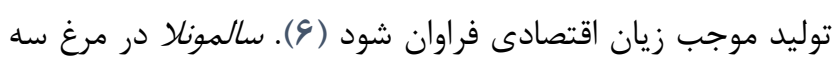

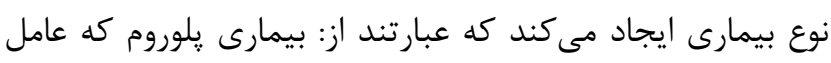

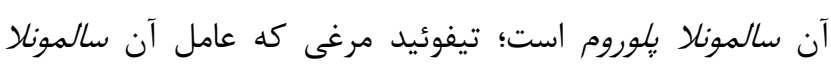

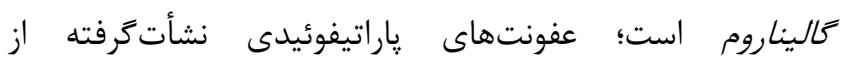

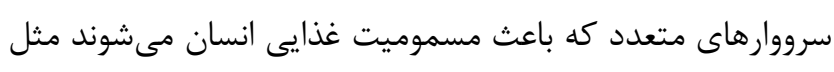

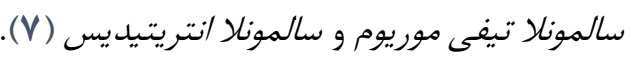
از وقوع سالمونلوزيس در انسان كه منبع آن تخممرونهاي

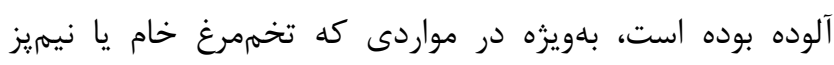

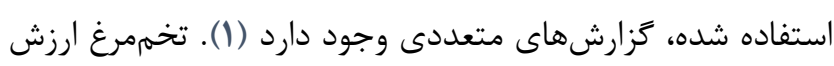

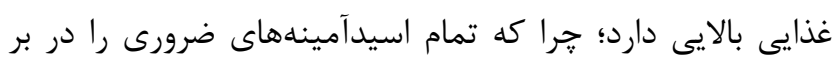

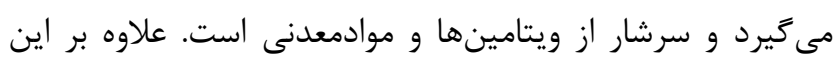

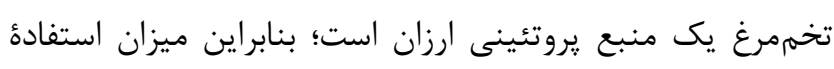

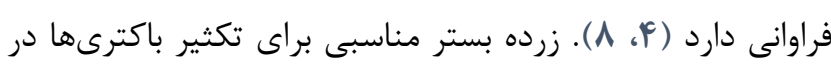

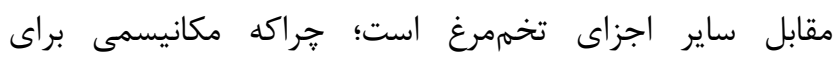

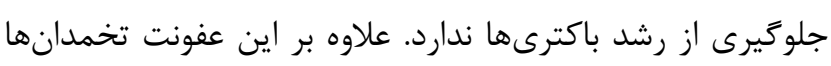

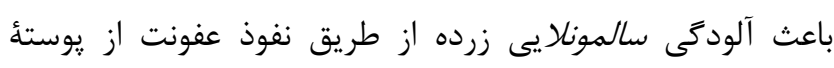

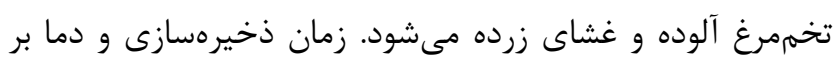

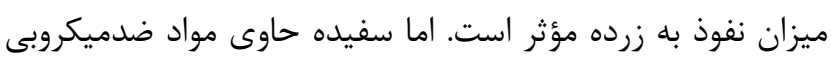

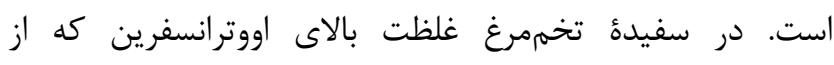

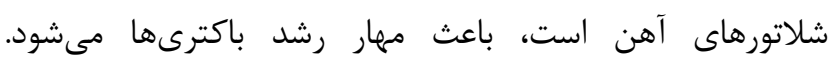

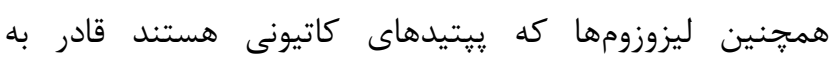

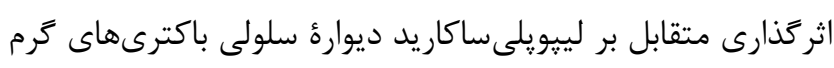
منفى هستند و باعث تشكيل منافذى مىشوند كه موجب نفي نفوذ 
اختصاصى سالمونلاى تهيهشده از شركت بهار افشان، طبق دستور العمل شركت سازنده استفاده شد.

DNA استخراج

براى استخراج DNA، يركّنهاى مشكوك به سالمونلا در

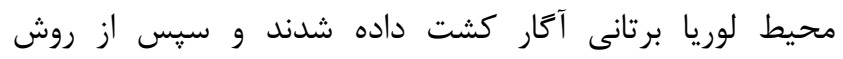

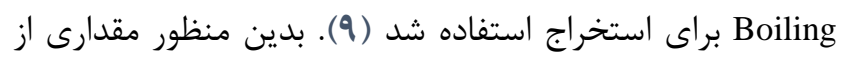

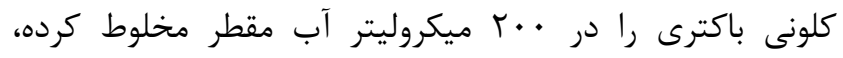
بهطورى كه كدورتى معادل استاندارد نيم مك فارلند (معادل

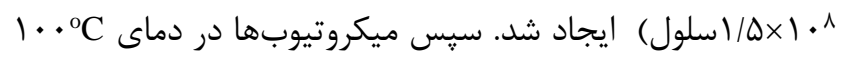

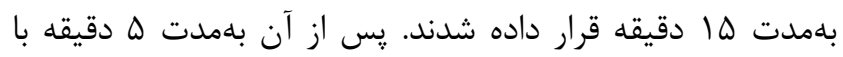

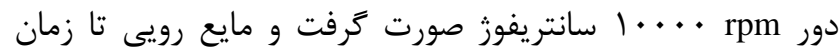
انجام آزمون PCR در فريزر • •r- نتخهدارى شد.

\section{PCR تشخيص جنس سالمونلا با آزمون}

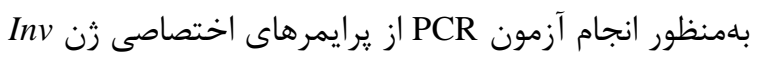
A(تهيهشده از سوى شركت سينازن) كه كدكننده يروتئين غشاى

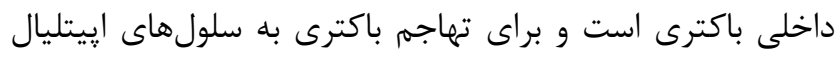

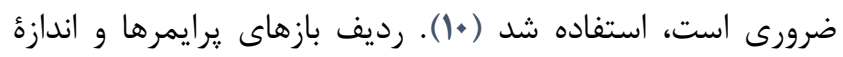

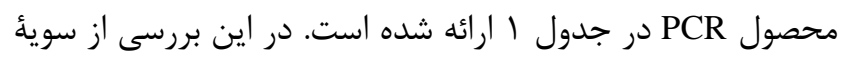

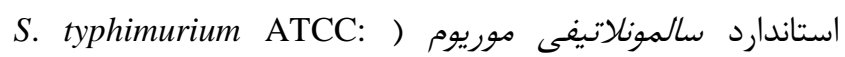

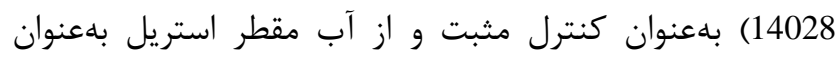

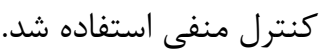

حجم له سىسى انتقال داده شد. براى سفيده نيز اين مرحله انجام

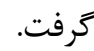
از يك تخممرغ سـه نمونه محيط لاكتوز براث حاوى زرده،

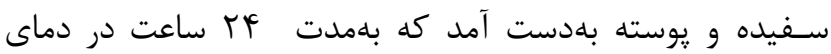
صن صنعتى و • DF نمونه تخممرغ بومى در محيط لاكتوز براث و ريشغنىسازى شد. بهمنظور غنىسازى از محيط سلنيت

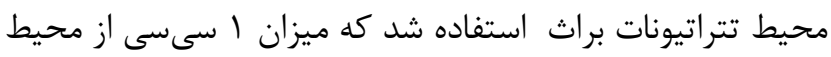
ييشغنىشده به 9 سىسى از محيطهاى مذكور افزوده شد.

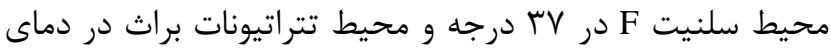

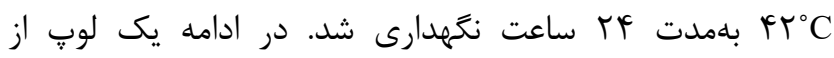

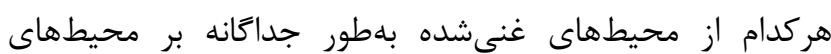

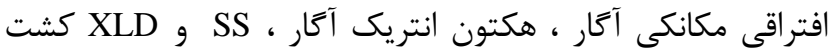

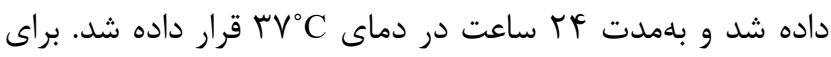

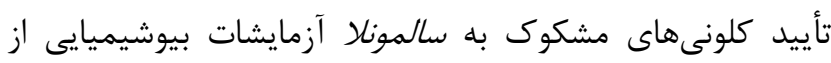
جمله كشت در سيمون سيترات ، اوره آكار (Merck, Germany)، (Merck, Germany) MR-VP و TSI

\section{سروتايِينَ}

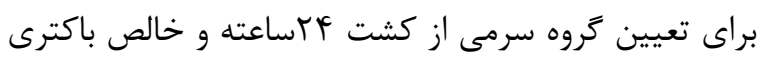
در محيط TSI با استفاده از آنتىسرمهاى اختصاصى استفاده شد.

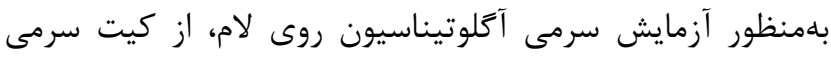

جدول ا. يرايمرهاى استفادهشه براى شناسايى زن Inv A

\begin{tabular}{|c|c|c|c|c|}
\hline 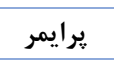 & توالى يرايمر & 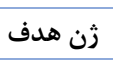 & طول محصول (bp) & 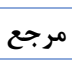 \\
\hline S139-F & a'-GTGAAATTATCGCCACGTTCGGGCAA-r' & \multirow{2}{*}{$\operatorname{Inv} A$} & \multirow{2}{*}{ rAF } & \multirow{2}{*}{ 1. } \\
\hline S141-R & ఎ'-TCATCGCACCGTCAAAGGAACC-r' & & & \\
\hline
\end{tabular}

براى تعيين سرووارهاى سالمونلا انتريتيديس، سالمونلا تيفى

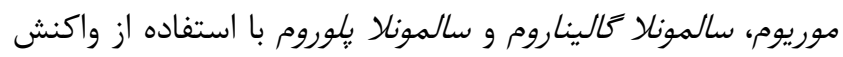

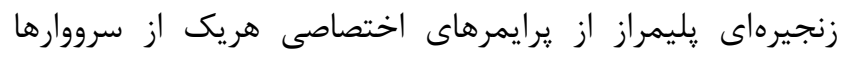

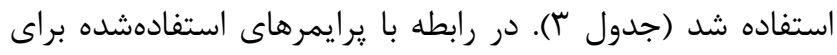

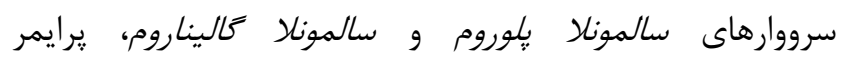
طراحىشده كدكننده بخشى از زن ratA است كه محصول آن

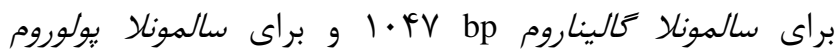
دهد bp

دهد.

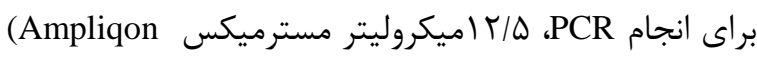

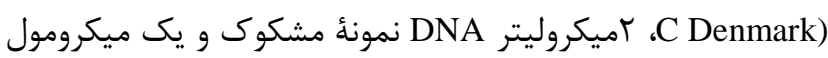
از يرايمرهاى S139 و S141 با غلظت • إيكومول استفاده شد و

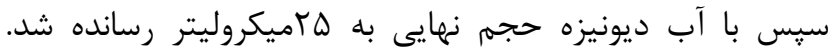
برنامة زمانى و دمايى ترمال سايكلر (Primus 96 (Germany) مطابق با جدول شماره r انجام شد. الكتروفورز محصولات PCR از سوى دستخاه الكتروفورز (Sigma, USA) \% بر زل آكاروز الهوي (Padideh Nojen Pars, Iran)

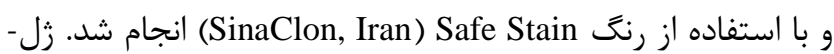
ها با استفاده از دستخاه زل داك (Syngene, England) بررسى آنى 


\begin{tabular}{|c|c|c|}
\hline & \multicolumn{2}{|c|}{ جدول r. سيكلهاى حرارتى بهمنظور تكثير ثن Inv A } \\
\hline 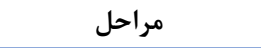 & درجه حرارت (م) & 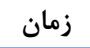 \\
\hline Initial denaturation & 90 & 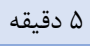 \\
\hline Denaturation & $9 \Delta$ & أ ثانيه \\
\hline Annealing & $\Delta \varphi$ & هأ ثانيه \\
\hline Extension & vr & هاf ثانيه \\
\hline Final extension & VT & 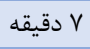 \\
\hline Cycle number & & r. \\
\hline
\end{tabular}

\begin{tabular}{|c|c|c|c|c|c|}
\hline \multicolumn{6}{|c|}{ جدول r. توالى يرايمر هاى استفادهشده بهمنظور شناسايى سرووارهاى سالمونلا } \\
\hline 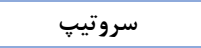 & 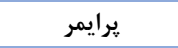 & 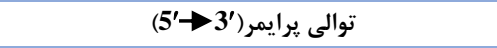 & 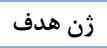 & طول محصول(bp) & 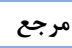 \\
\hline \multirow{2}{*}{ سالمونلا تيفى موريوم } & Flic-s & ATAGCCATCTTTACCAGTTCCCCC & \multirow{2}{*}{ fliC } & \multirow{2}{*}{ int } & \multirow{2}{*}{11} \\
\hline & Flic-as & GCTGCAACTGTTACAGGAATATGCC & & & \\
\hline \multirow{2}{*}{ سالمونلا انتريتيديس } & SefA2 & GCAGCGGTTACTATTGCAGC & \multirow{2}{*}{ SefA } & \multirow{2}{*}{ r. } & \multirow{2}{*}{ ir } \\
\hline & SefA4 & TGTGACAGGGACATTTAGCG & & & \\
\hline سالمونا كاليناروم & ratA Forward & \multirow{2}{*}{$\begin{array}{l}\text { GACGTCGCTGCCGTCGTACC } \\
\text { TACAGCGAACATGCGGGCGG }\end{array}$} & \multirow{2}{*}{ ratA } & $1 .+V$ & \multirow{2}{*}{ ir } \\
\hline سالمونا بلوروم & ratA reverse & & & TFr & \\
\hline
\end{tabular}

سالمونلا تيفى موريوم، سالمونلاكاليناروم و سالمونلا بيلوروم صورت كَرفت كه هيجيك از سرووارهاى مدنظر مشاهده نشد.

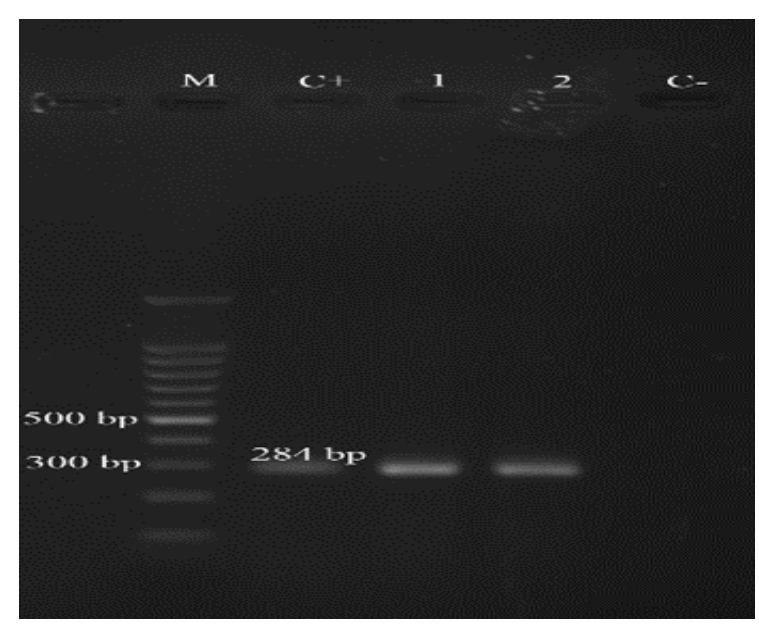

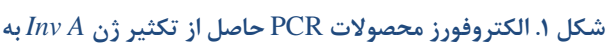

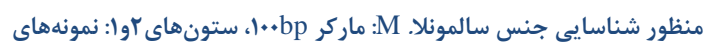

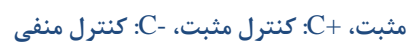

مافته ها

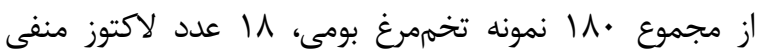

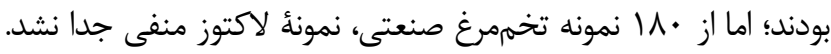

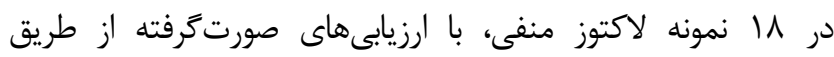
تستهاى بيوشيميايى و محيطهاى كشت افتراقى هيج يرگنه مشكوك

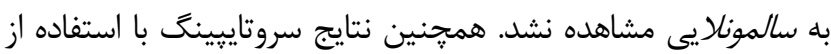

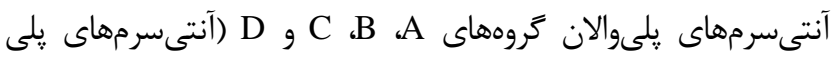
والان O شركت بهارافشان، ايران) منفى بود. اما يس از بررسى با آنتى-

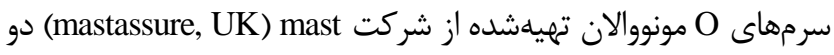
نمونه سالمونلا نيواينگتون تشخيص داده شد. در آزمون PCR كه با استفاده از يرايمرهاى اختصاصى زن تئinvA براى تعيين جنس سالمونلا انجام گرفت، از \1 نمونه لاكتوز منفى ب نمونه (يك زرده و يكى سفيده) مثبت شدند (جدول \&) كه براى آنها باند TAF bp قابل مشاهده بود

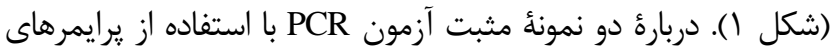
اختصاصى بلهنظور شناسايى سرووارهاى سالمونلا /تتريتيديس،

جدول F. ميزان آلودَى سلمونلايى تخممرغ هاى بومى با استفاده از PCR

\begin{tabular}{|c|c|c|c|}
\hline درصد آلودگى & موارد مثبت & تعداد نمونه (تخممرغ بومى) & 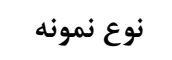 \\
\hline$\cdot$ & . & \multirow{4}{*}{11.} & يوستهٔ تخممرغ \\
\hline$\cdot 10$ & 1 & & زرده تخممرغ \\
\hline$\cdot 10$ & 1 & & سفيدهٔ تخممرغ \\
\hline $1 / 1$ & r & & مجموع \\
\hline
\end{tabular}


البته نتايج آنها با مطالعهُ ما همخوانى ندارد؛ زيرا در بررسى حاضر،

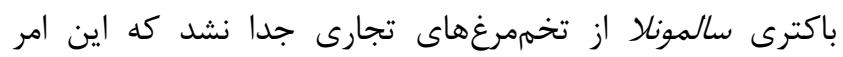

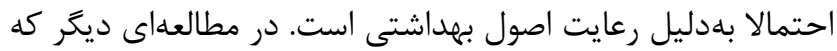

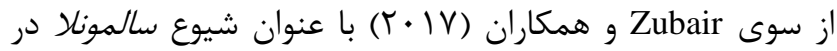

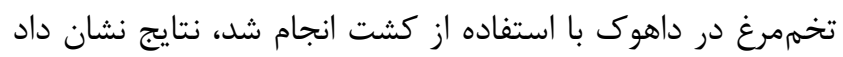

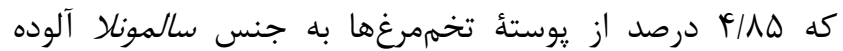

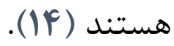

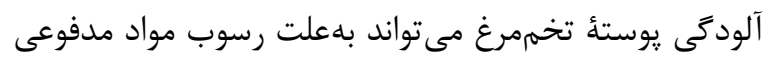

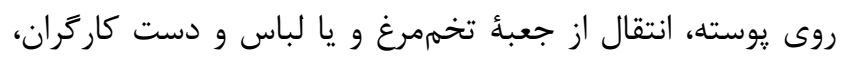
هنخام بستهبندى و ذخيرهسازى، تردوغبار، محيط زيست، شرايط آبوهوايى و يا در حين حملونقل صورت يذيرد (هإ). همجنين

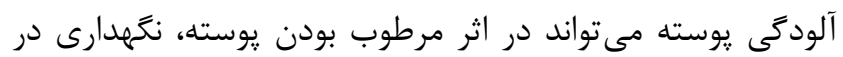

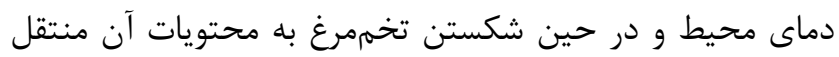
شود و باعث بروز مسموميت غذايى در انسان شود (1) (F). البته باكترى بهطور مستقيم مى تواند از تخمدان باعث آلودگى محتويات تخممرغ شود.

طى بررسى ایى كه از سوى Fardows و همكاران (ها • (Y)،

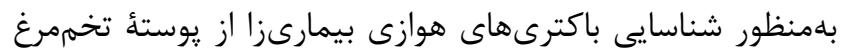

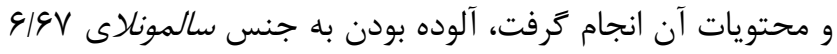

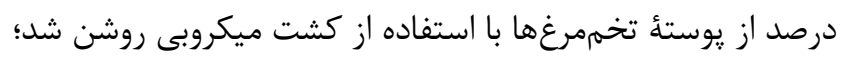

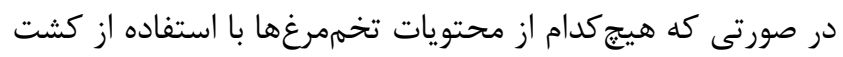
بمنظور تشخيص آلودكى مثبت نبودند. اما با استفاده از تكنيك نمونه از محتويات تخممرغها و PCR

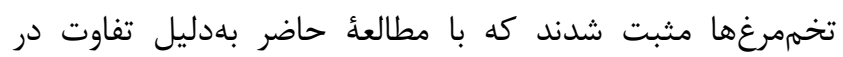
منطقة جغرافيايى و روش بررسى همخوانى ندارد (19). Moraes و همكاران (19 • (Y) كه مطالعهاى بلمنظور بررسى جنس سالمونلا در تخممرغهاى تجارى سفيد و قهوهاى شستهشده و شستهنشده با استفاده از كشت و qPCR در برزيل انجام دادند، به وائ اين نتيجه

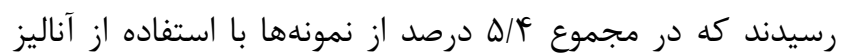

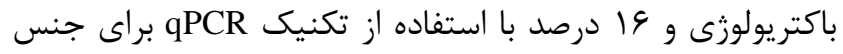

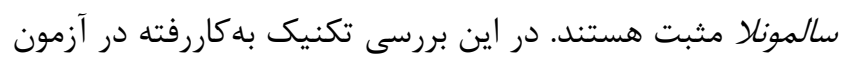

و روش بررسى با مطالعأ ما همخوانى ندارد (A).

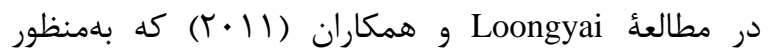
تشخيص سالمونلا در نمونهاى تخممرغى كه از سيستمهاى

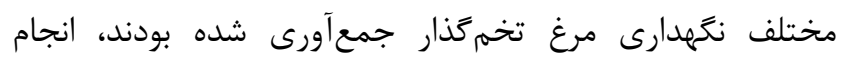

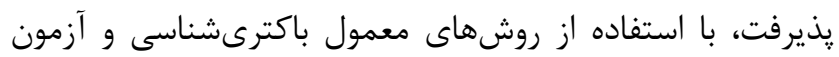

\section{بحث}

بررسىهاى انجامكرفته در مناطق مختلف ايران نشان داده

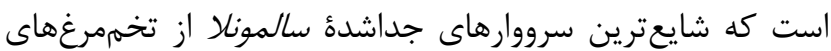

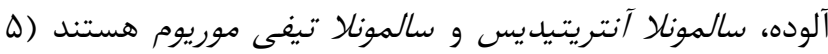

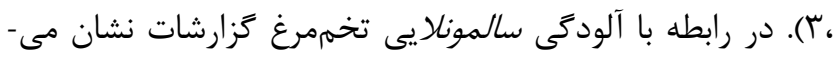

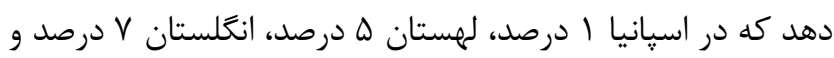

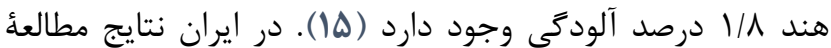
Mozaffari هاى محلى و صنعتى به سالمونلا در تالش، نشان داد كه 19 درصد

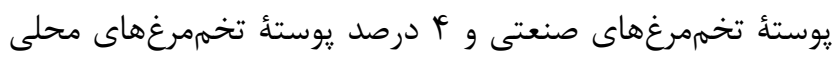
آلوده به سالمونلا ld هستند (1) كه با مطالعئ حاضر بهدليل

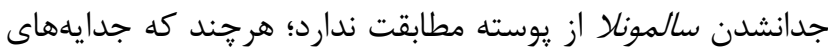

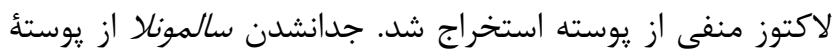

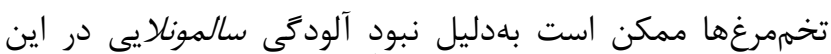
منطقه و يا آلودگى با فراوانى اندك باشد كه با اين تعداد نمونه

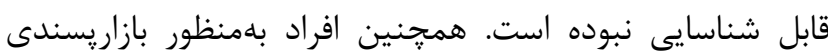

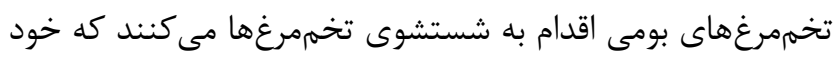
باعث يايين آمدن بار ميكروبى بر يوستهُ تخممرغ مىشود. همجنين در مطالعه ديكرى كه از سوى Monadi و همكاران

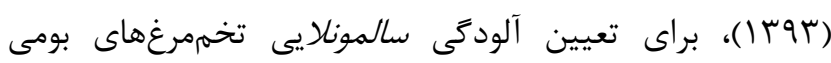

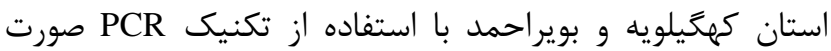

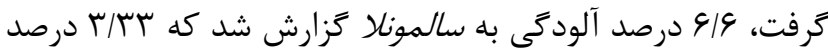

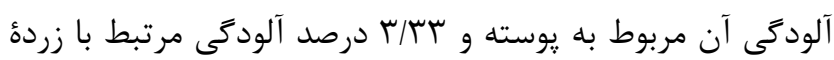

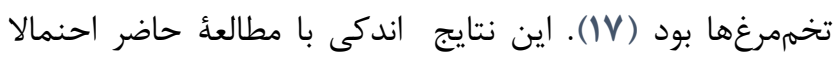

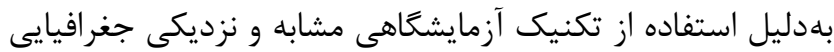

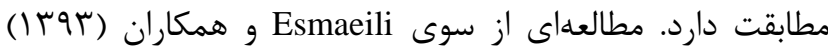
بلمنظور تعيين سرووارهاى سالمونلا در تخممرغهاى إن بومى إنى استان

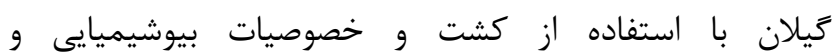
سروتاييِينَ انجام گرفته است كه براساس آن آلودگى يك نمونه

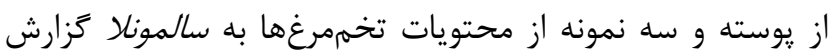

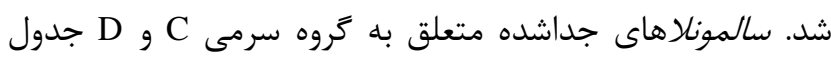

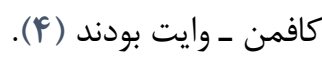
در مطالعهاى كه از سوى Moosavy و همكاران (T) (T)

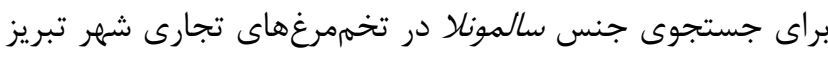

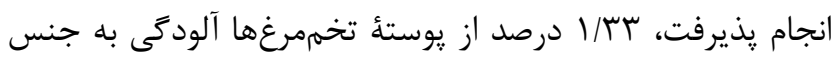
سالمونلا داشتند كه سرووار انتريتيديس و تيفى موريوم بودند ((). 
تماس بوده نيز مىتواند باعث آلودگى يوسته شود، اما آلودگى

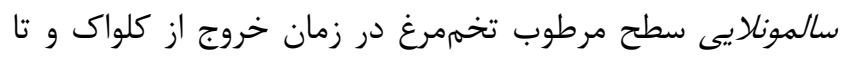

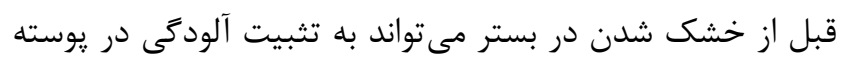

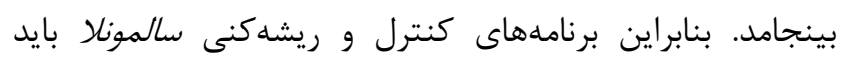

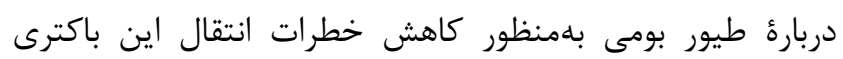

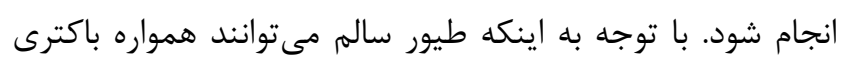

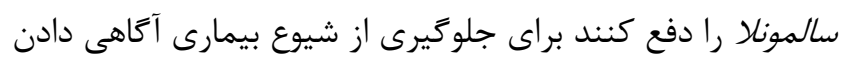

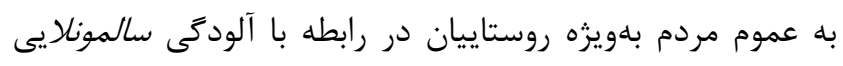

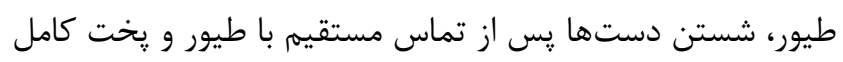
تخممرغ براى جلوكيرى از بيمارى كمك كننده هستند.

$$
\text { نتيجه }
$$

هدف از انجام اين مطالعه، بررسى ميزان شيوع سرووارهاى

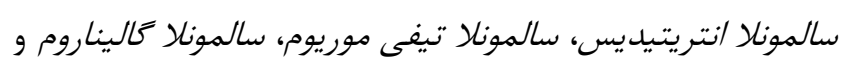

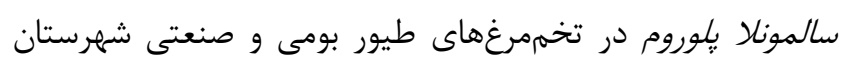

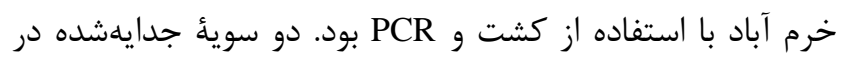

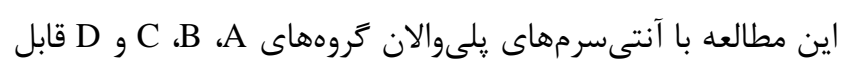

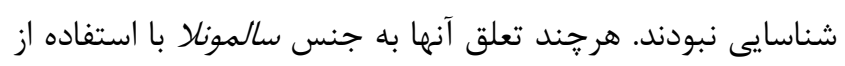

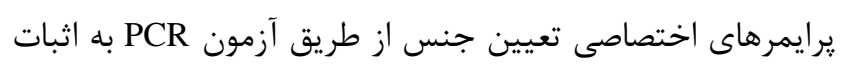

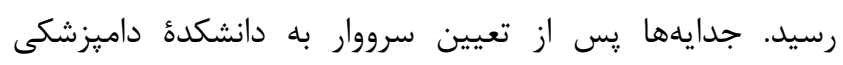

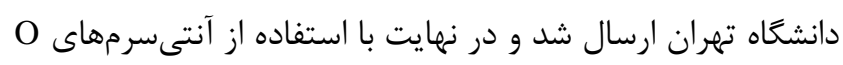

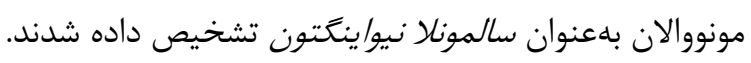

$$
\text { سياسگزارى }
$$

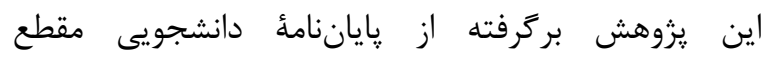

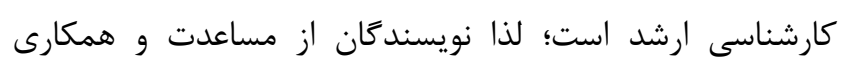

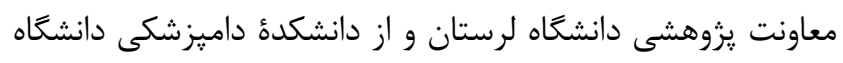
تهران تشكر و قدردانى مى كنند.

$$
\text { تعارض منافع }
$$

بين نويسندگان تعارض در منافع تزارش نشده است.

\section{References}

1. Moosavy MH, Esmaeili S, Bagheri Amiri F, Mostafavi E, Zahraei Salehi T. Detection of Salmonella spp in commercial eggs in Iran. Iran $\mathbf{J}$ Microbiol. 2015;7(1):50-4. PMID:26644874 PMCID:PMC4670468

2. Basler C, Nguyen TA, Anderson TC, Hancock T, Behravesh CB. Outbreaks of Human Salmonella Infections Associated with Live Poultry, United States, 1990-2014. Emerging Infect Dis.
نشان داده شد كه له درصد از يوسته تخممرغها به جنس سالمونلا آلوده هستند (•r). اين مطالعات نشان مىدهند كه بين روشهاى تشخيصى، روش PCR بهدليل حساسيت و سرعت بالا،

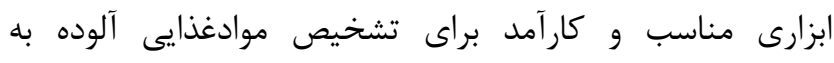

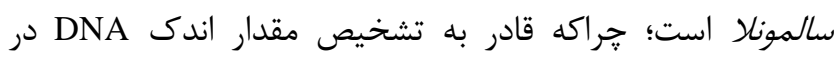

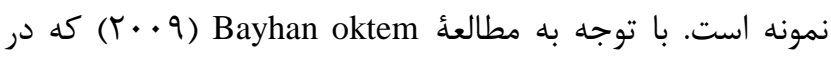

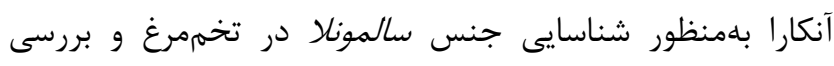
حيات باكترى در دماى يخجال و جوش صورت زرفت، 9 درصد از

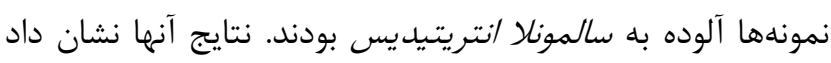

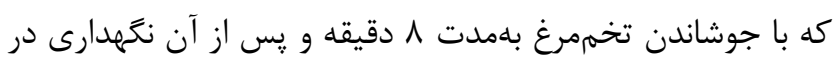

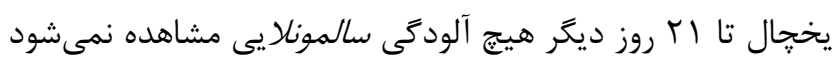

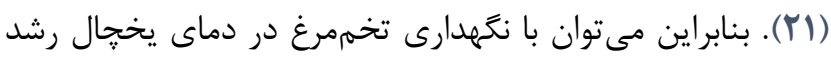

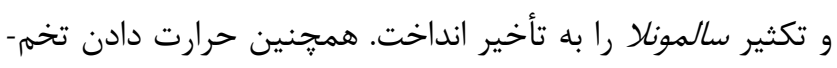

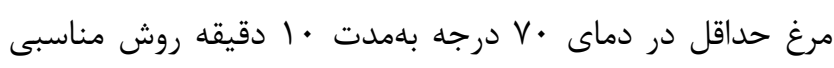
براى جلوخيرى از انتقال آلودگى است.

بهطور كلى در خصوص مرغدارىهاى تخمىذار صنعتى، نبودن آلودگى قابل ييشبينى بود؛ زيرا مزارع تخمزَذار تجارتى و

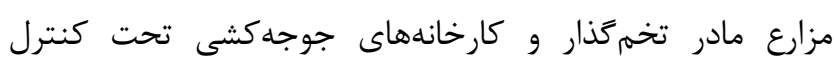
سازمان داميزشكى هستند و تحت شرايط قرنطينهاى و آزمايشات

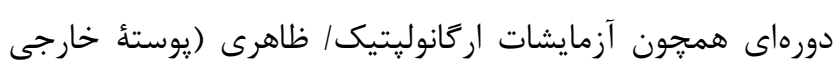

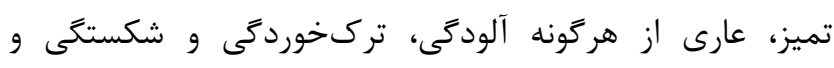

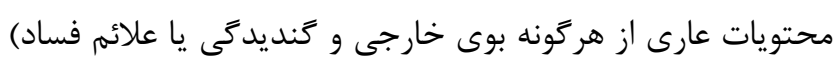

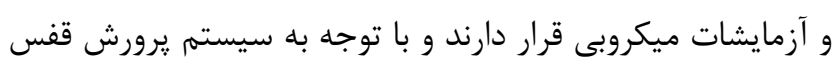

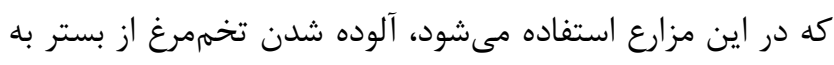
حداقل مىرسد.

اما در تخممرغهاى بومى وجود آلودگى دور از انتظار نبود كه اين امر ممكن است بهدليل آلودگى مرغان بومى با منشأ كلواك يا

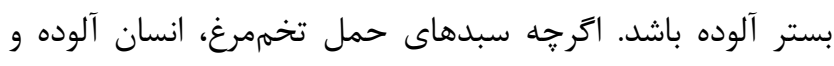

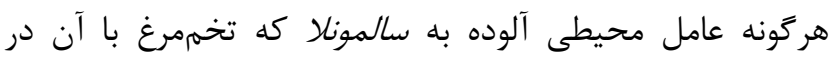

2016;22(10):1705-11.

https://doi.org/10.3201/eid2210.150765

PMID:27649489 PMCID:PMC5038410

3. Zahedi M, Rahimi E, Zahedi M, Momtaz H, Shojaii H. Prevalence of Salmonella enteritidis and S. typhimurium in marketed meat in Shahrekord in 2014. J Shahrekord Univ Med Sci. 2017;19(2):88-97.

4. Esmaeili H, Hamedi M, Salmonella's Serotypes in Domestic Eggs in Gilan Province. Iran J Infect Dis 


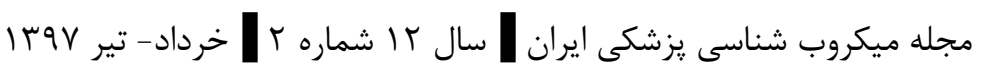

Trop Med. 2014;19(65):39-45.

http://www.iiccom.org/JOURNAL/PDF/65/7.PDF

5. Madadi MS, Yousefi K. Experimental vertical transmission of different doses of Salmonella Enteritidis in Broilers chickens. Iranian Journal of Veterinary Clinical Sciences. 2016;9(2):69-77.

6. Jafari RA, Fazlara A, Dalirannia A, An investigation into Salmonella contamination of native hens' eggs in Ahvaz. Iranian Veterinary Journal. 2006;2(2):58-63. http://www.sid.ir/en/journal/ViewPaper.aspx?ID=930 $\underline{00}$

7. Oliveira SD, Santos LR, Schuch DMT, Silva AB, Salle CTP, Canal CW. Detection and identification of salmonellas from poultry-related samples by PCR. Vet Microbiol. 2002;87(1):25-35. https://doi.org/10.1016/S0378-1135(02)00028-7

8. Moraes DMC, Duarte SC, Bastos TSA, Rezende CLG, Leandro NSM, Café MB, et al. Detection of Salmonella spp. by Conventional Bacteriology and by Quantitative Polymerase-Chain Reaction in Commercial Egg Structures. Rev Bras Cienc Avic. 2016;18(1):117-24. https://doi.org/10.1590/18069061-2015-0063

9. Zahraei Salehi T, Tadjbakhsh H, Atashparvar N. Detection and identification of Salmonella Typhimurium in bovine diarrhoeic fecal samples by immunomagnetic separation and multiplex PCR assay. Zoonoses Public Health. 2007;54(6-7):231-6. https://doi.org/10.1111/j.1863-2378.2007.01061.x PMID: 17803511

10. Rahn K, De grandis SA, Clarke RC, Mcewen SA, Galan JE, Ginoccho C, et al. Amplification of an invA gene sequence of Salmonella typhimurium by polymerase chain reaction as a specific method of detection of Salmonella. Mol Cell Probes. 1992;6(4):271-9. $\quad$ https://doi.org/10.1016/08908508(92)90002-F

11. Lim YH, Hirose K, Izumiya H, Arakawa E, Takahashi H, Terajima J, et al. Multiplex polymerase chain reaction assay for selective detection of Salmonella enterica serovar Typhimurium. Jpn J Infect Dis. 2003;56(4):151-5. PMID:14583637

12.Pan TM, Liu YH. Identification of Salmonella Enteritidis isolates by polymerase chain reaction and multiplex polymerase chain reaction. $\mathrm{J}$ Microb Immunol Infec. 2002;35(3):147-51. PMID: 12380786

13. Lopes P, Neto OF, Batista D, Denadai J, Alarcon M, Almeida A, et al. Experimental infection of chickens by a flagellated motile strain of Salmonella enterica serovar Gallinarum biovar Gallinarum. Vet J. 2016;214:40-6. $\quad$ https://doi.org/10.1016/j .tvj1.2016.05.006 PMID:27387725
14.Zubair AI, Al-Berfkani MI, Issa AR. Prevalence of Salmonella species from poultry eggs of local stores in Duhok. Int J Res Med Sci. 2017;5(6):2468-71. https://doi.org/10.18203/2320-6012.ijrms20172430

15. Ghasemian Safaei H, Jalali M, Hosseini A, Narimani T, Sharifzadeh A, Raheimi E. The prevalence of bacterial contamination of table eggs from retails markets by Salmonella spp., Listeria monocytogenes, Campylobacter jejuni and Escherichia coli in Shahrekord, Iran. Jundishapur J Microbiol. 2011;4(4):249-53.

16. Mozaffari NA, Rahmani Z, Iesazadeh K. Evaluation of the level of contamination with Salmonalla spp. In Red meat, Chicken, and Domestic and Industrial Eggs produced in Talesh City and assessment of their antibiotic resistance pattern, Iran. Qom Univ Med Sci J. 2013;7(5):60-5.

17. Monadi M, Kargar M, Naghiha A, Mohammadi R. Salmonella contamination of eggs of native Kohgiluyeh va Boyerahmad using PCR1 techniques and the evaluation of drug resistance. Armaghane Danesh. 2014;19(2):178-87. http://armaghanj.yums. ac.ir/article-1-445-en.html

18. Amin Zare M, Nairiz naghade M, Rasoli S, Delshad R. Isolation of Salmonella spp. from local egg yolks in Urmia. Clinical Research of Large Livestock. 2009;7(3):51-5. http://www.sid.ir/FileServer/ JF/25713880708

19. Fardows J, Shamsuzzaman SM. Detection of potential pathogenic aerobic bacteria from egg shell and egg contents of hen collected from poultry. Bangladesh Med Res Counc Bull. 2015;41(2):67-72. https://doi.org/10.3329/bmrcb.v41i2.29983 PMID:29624284

20.Loongyai W, Wiriya B, Sangsawang N. Detection of Salmonella and Escherichia coli in Egg Shell and Egg Content from Different Housing Systems for Laying Hens. Int J Poult Sci. 2011;10(2):93-7. https://doi.org/10.3923/ijps.2011.93.97

21. Bayhan oktem A, Kaynak onurdag F, Buket ER, Demirhan b. A research of salmonella spp. In egg and egg products and survival of salmonella in different temperatures. Turk J Pharm Sci. 2009;6(3):147-54. 